\title{
USING CHATBOTS IN MARKETING COMMUNICATION
}

\author{
Agnieszka Werenowska, $\mathrm{PhD}^{1 *} ;$ Ewa Jaska, $\mathrm{PhD}^{2^{* *}}$ \\ Faculty of Economic Sciences, Warsaw University of Life Sciences - SGGW \\ ${ }^{*}$ https://orcid.org/0000-0002-2545-4442 \\ ${ }^{* *}$ https://orcid.org/0000-0002-3874-1985
}

\begin{abstract}
The e-commerce industry is constantly growing and becoming a strong competition for stationary outlets. More and more e-stores are deciding to use new communication solutions. Many of them use so-called bots. The article presents the possibilities of using virtual assistants, the analysis of the literature on the subject and the results of conducted surveys on the use and familiarity of chatbots among recipients and managers. In the application of virtual assistants, managers see a chance to increase the possibility of effective communication with simultaneous reduction of the costs of carrying out this process. The benefits of this solution support the intensive and versatile use of it. At the same time, customers opt for direct contact with a consultant. That is why the perfect combination is to have both a chatbot and a real consultant.
\end{abstract}

Key words: marketing, chatbot, communication

JEL code: 031

\section{INTRODUCTION}

All companies that want to be visible and recognizable on the market care about their marketing communication. They have a number of tools at their disposal that facilitate the organization of such a process. Marketing communication management itself is currently a targeted activity to regulate market stability through information technologies. They enable consumers to obtain information about products and services and allow to learn about consumers' needs. The development and spread of new technologies gives many opportunities, including communicational possibilities. One of the instruments filling the communication space between the producer and the consumer are chatbots. Using instruments from the new technologies category is the domain of the $\mathrm{Y}$ and $\mathrm{Z}$ generation. These are people born between 1980-1999 and after 2000 respectively. They are often referred to collectively as the Millennials, due to the fact that they entered the labour market at the turn of two centuries. Their representatives are brought up in the age of the Internet which has no secrets for them. They cope very well with technological innovations, from which they expect pragmatism and simplification in everyday life. Generation $\mathrm{Y}$ is the first generation that grew up in the world dominated by computers, mobile phones, multimedia devices and online social networks. In turn, the generation $\mathrm{Z}$ is a generation that had never existed before. This young generation born after 1995 significantly outperforms their predecessors in terms of knowledge about the use and utilization of the Internet, mobile devices. The

\footnotetext{
${ }^{1}$ Corresponding author: Nowoursynowska 166, 02-787 Warsaw, Poland, agnieszka werenowska@sggw.pl, +48 664198540

${ }^{2}$ Corresponding author: Nowoursynowska 166, 02-787 Warsaw, Poland, ewa_jaska@sggw.pl, +48 607777733
} 
reason for this is communing in a completely natural environment for them. At the same time, it is a generation that in the era of new technologies cannot function without it (Jaska and Werenowska, 2018).

The article presents the possibilities of using chatbots in marketing communication. It analyses literature on the subject and the results of the survey carried out. In the survey, the groups of respondents were: representatives of companies using chatbots for marketing purposes (IT companies), potential recipients of virtual assistants services. The method of the diagnostic survey was used. A questionnaire was used among potential service users. However, among the representatives of companies using chatbots, there is an interview questionnaire.

\section{THE ESSENCE OF COMPUTER COMMUNICATION}

Transformations in the way of marketing communication have a very deep dimension. The so-called hypermedia computer environment "creates a new quality of marketing communication: the collection, storage, processing, presentation and transmission of information between the sender and the potential recipient of the message" (Wiktor, 2013, 249).

In literature, the term "marketing communication" refers to a dialogue of the enterprise with other entities in its market environment, constituting the foundation of marketing and the condition for market success of each institution (Wiktor, 2005). Communication via a computer is a type of communication in which communicators do not have face-to-face contact but talk using computer-assisted communication technologies (Pyżalski, 2012). The specific, yet common communication via a computer is possible thanks to the coexistence of four basic elements (Grębosz, Siuda and Szymański, 2016):

- sender, who has access to a computer or a device from which information is transmitted and sent; recipient, who has access to a device that receives information; message in the form of a code sent to the recipient by the sender as text, image, video, sound, etc.

- the channel through which the information sent, which is at the same time the carrier of the code. The indisputable attribute of hypermedia commu- nication is its selectivity to a degree unattainable for traditional mass media communication. This means that the new communication environment offers sellers the opportunity to appear on the market through the presence of their offer on the web and recipients decide what, where and what time to browse. This is the ground of individual recipient's decision (Wiktor, 2002).

Nowadays, two trends are noticeable that influence the development of communication tools: the integration of communication channels and the use of modern interactive technologies. These phenomena generate the need for interactive communication which is why the Internet plays such an important role in the processes of marketing communication (Taranko, 2015). Whereas one of the increasingly popular marketing communication tools are so-called chatbots.

\section{THE CONCEPT AND USE OF CHATBOTS}

Chatbots are still new solutions, although the first computer programs that can be called chatbots appeared around 1966 as attempts to implement the CMC (Computer Mediated Communications) project whose aim was to establish a human-computer connection. The concept itself is an abbreviation of the word "robot". Its task is to imitate human behaviour in specific cases. A chatbot accomplishes two basic goals: it satisfies the client's needs and provides automation of communication. It is used in situations when contact with recipients is based on repetitive processes, it can answer typical questions, check the available date of appointment or encourage purchase of a desired product (Nowy Marketing, 2018). To define it in the simplest way chatbots are computer programs that simulate the operation of live users. According to the report "Polish Chatbots 2018", Internet bots currently account for over $50 \%$ of all activity on the Internet - including websites browsing, content publishing, media playing or downloading files on portal https://projekty.k2.pl.

Today, many types of electronic assistants can be distinguished. One of the taxonomies is chatbots classification: notifying; process; conversational (Table 1).

Conversational chatbots have become particularly popular. Consumers and customers often ask the same questions. In order to maintain high quality of 
Table 1. Classification of chatbots and sample tasks

\begin{tabular}{|l|l|l|}
\hline Type of chatbot & \multicolumn{1}{|c|}{ Communication method } & \multicolumn{1}{|c|}{ Examples } \\
\hline Notifying & $\begin{array}{l}\text { One-way communication to users, sends notifica- } \\
\text { tions in accordance with the established schedule, } \\
\text { works similarly to a "newsletter". }\end{array}$ & $\begin{array}{l}\text { notification of sending a package, weather forecast } \\
\text { news from the country and from all over the world }\end{array}$ \\
\hline Process & $\begin{array}{l}\text { The process allows the user to go through a pre- } \\
\text { determined and linear process, requiring a series of } \\
\text { decisions from a closed pool of choices. }\end{array}$ & $\begin{array}{l}\text { purchase of tickets to the cinema, online shopping } \\
\text { from the messenger, selection of a holiday offer of } \\
\text { a travel agency, submitting an application to open } \\
\text { a bank account }\end{array}$ \\
\hline Conversational & $\begin{array}{l}\text { Allows the user for casual conversation, following } \\
\text { instructions answers questions asked in the lan- } \\
\text { guage of the user. }\end{array}$ & implementation of the FAQ office \\
\hline
\end{tabular}

Source: own study based on information from portal https://projekty.k2.p1/

service and customer satisfaction a possibility of answering a very wide range of questions at different times becomes almost a standard. It must be remembered that from the point of view of a brand, a satis- fied customer significantly influences the company's success. Chatbots have various applications. Thanks to the possibilities they create, they are used in the implementation of many tasks (Table 2).

Table 2. Possible applications of chatbots

\begin{tabular}{|c|c|c|}
\hline Task & Implementation tasks & Benefits \\
\hline Entertainment & Building of an emotional connection with clients. & $\begin{array}{l}\text { Credibility and plasticity of the website; time spent } \\
\text { on the website, more frequent return to it; attracting } \\
\text { potential customers; an offer presented in an at- } \\
\text { tractive way; openness to receiving information. }\end{array}$ \\
\hline $\begin{array}{l}\text { Guide to the } \\
\text { website service }\end{array}$ & $\begin{array}{l}\text { Information interesting for the client and familiari- } \\
\text { zation with the offer. }\end{array}$ & $\begin{array}{l}\text { Effective finding of the information sought; indica- } \\
\text { tion of information based on the answers to que- } \\
\text { stions; personalization of the company's website. }\end{array}$ \\
\hline $\begin{array}{l}\text { Virtual } \\
\text { spokesman }\end{array}$ & Creating a good company and product image. & $\begin{array}{l}\text { Works } 24 \text { hours a day; ease of adaptation to chan- } \\
\text { ges; currentness. }\end{array}$ \\
\hline e-marketing & $\begin{array}{l}\text { Dialogue focused on acquiring information; building } \\
\text { an emotional connection with clients; collecting kno- } \\
\text { wledge about individual customer preferences. }\end{array}$ & $\begin{array}{l}\text { Low research costs; readiness to talk with the custo- } \\
\text { mer at any time; ability to talk about general topics; } \\
\text { obtaining information about customer preferences. }\end{array}$ \\
\hline $\begin{array}{l}\text { Customer } \\
\text { adviser }\end{array}$ & Providing advice on purchased products. & Easy and continuous access to information. \\
\hline Consultant & A quick, competent and friendly response. & $\begin{array}{l}\text { Lack of technical limitations as to the number of cu- } \\
\text { stomers simultaneously conversing with a chatbot; } \\
\text { instant service for all current customers. }\end{array}$ \\
\hline Seller & $\begin{array}{l}\text { Familiarization with the range of products; answers } \\
\text { to questions; assistance in making a choice based } \\
\text { on an analysis of customer's needs and expectations } \\
\text { resulting from the interview. }\end{array}$ & $\begin{array}{l}\text { Increase sales with cross selling; shortening of the } \\
\text { procedures of product purchase; reduction in the } \\
\text { number of interrupted purchases due to lack of in- } \\
\text { formation. }\end{array}$ \\
\hline
\end{tabular}

Source: own study based on Pawlak and Wolski (2007). 


\section{USING CHATBOTS IN MARKETING COMMUNICATION IN THE LIGHT OF OWN RESEARCH}

Contemporary, consumers often look for information about the company that interests them on the website or on Internet forums. Sometimes, however, this information is insufficient. In such situations consultants or chatbots are used. For enterprises such a solution gives the possibility to minimize the costs of customer service. Managers are very optimistic about this solution. The four interviews conducted with experts in 2018 show that in addition to reducing costs they also see in this solution acceleration of communication, e.g. by partially replacing e-mailing. According to experts, chatbot isn't yet a very effective tool and cannot change the conversation with a company employee. The key problem at a given stage of development and use of chatbots is low consumer awareness of their existence and use of the communication.

From a technical point of view, the use of chatbots by companies means, first of all, maintaining the fluency in communication, reaching a huge number of recipients and fast delivery of messages. It can be assumed that bots will be increasingly used by companies for communication with clients. In the midst of benefits for users should be included among others the following (SALESmanago, n.d.):

- recommending in real time products and services tailored to the needs and interests of consumers;

- simple implementation;

- creating multilingual conversations;

- possibility to plan a full conversation with the client;

- unlimited number of scenarios;

- support for the work of the marketing and customer service department;

- extending communication with the client with a new channel;

- reaching with the offer the wider range of users;

- standing out from the competition.

We should also mention the costs of introducing and operating chatbots. The final cost of preparing the bot and implementing it on the fanpage varies and depends on many factors. These include, among others, the desired functionalities, the number of user paths, integration with external data sources, marketing development, etc. Among the offers of companies that run the service and introduce chatbots prices start from several hundred zlotys a month. The price depends on the client's needs. The possibility of adjusting makes it an instrument more valued by managers. Consumers have a slightly different view of this specific tool. The survey was conducted in 2018 among 123 people between the ages of 20 and 24. It is worth mentioning that it is a group belonging to a generation in a special way involved in the use of new technologies in everyday life. More than half of the respondents knew the concept of chatbot (51\%) but was unable to define it which indicates a little knowledge of the tool and its use. Only $9 \%$ correctly defined it. It should be concluded that despite the increasing use of chatbots by companies, clients do not know exactly what it is used for and what is this virtual assistant. Most of the respondents also did not use chatbots at all or thought that they did not use the services of a virtual assistant. Only $4 \%$ of respondents stated that they often use chatbots.

Despite the popularity of chatbots in the communication they have gained among marketers, customers - users of this program still believe that it is not very effective and cannot match up to the conversation with a company employee. They unequivocally emphasize the importance of "live" consultants in customer service and their irreplaceability in matters related to customer service, especially in more complex matters. Although a chatbot is very attractive for companies, it is still not popular among consumers. The analysis of research results leads to the conclusion that many people are still suspicious of using chatbots and the possibilities they provide. Considering that $47 \%$ of the respondents could not define the concept of "chatbot", it may be suggested that the time to full use and acceptance of this technology among users is going to be very long. On this basis, it can be concluded that consumers still do not have full confidence in chatbots and communication with them and direct communication with a "live" consultant is the most effective and reliable. Dissatisfaction and distrust in relation to chatbots also showed the results of research conducted in the United States and 
the United Kingdom in 2017 among 3,000 consumers (van Lun, 2018). More than half (53\%) of the surveyed consumers (including 54\% in the USA and $52 \%$ in the United Kingdom) considered chatbots as "ineffective" or only "slightly effective". Consumers in the US were more strict in chatbots assessment, as $14 \%$ rated them as ineffective comparing to only $5 \%$ for British consumers. Interestingly, younger consumers thought that chatbots are more effective than older ones, as $22 \%$ of the surveyed representatives of the $\mathrm{Z}$ generation and $15 \%$ of Millennials rated them as "very effective". This is largely due to the positive attitude of young people to new technologies consumers (van Lun, 2018).

\section{SUMMARY AND CONCLUSIONS}

The e-commerce industry is constantly developing, becoming a competition for stationary outlets. More and more e-stores are deciding to use their own chatbots. The benefits of this solution support the intensive and versatile use of it. That's why the perfect combination is to have both a chatbot and a real consultant.

A well-programmed chatbot allows you to remember shopping preferences of customers. This, in turn, translates into building a customer relationship - if they come back to the store, they can expect a personalized offer and appropriately selected products in terms of size, colour or style. It also speeds up shopping and makes it easier to navigate the store which is of great importance especially when using mobile devices which, as indicated by numerous studies, are increasingly used by consumers. The advantages of implementing a chatbot in an e-store, however, do not only apply to customers. It is also a convenience for the service department as well as marketers. In addition to answering standard questions, a chatbot can quickly help you analyse what information customers are looking for, which elements on the site need updating or simplifying, and whether all the formalities on the website (application form, payment options, delivery method) correspond to the buyer's preferences. The main problem at a given stage of development and use of chatbots lies in the low awareness of consumers about their existence and the way they use a given message. However, as show the results of research carried out by the Gartner (2011) until 2020, up to $85 \%$ of customer interactions will take place without human intervention.

\section{REFERENCES}

1. Gartner (2011). Customer 360 Summit brochure. Retrieved from: http://www.gartner.com/imagesrv/ summits/docs/na/customer-360/C360_2011_brochure_ FINAL.pdf [Access 11.03.2019].

2. Grębosz, M., Siuda, D., Szymański, G. (2016). Social media marketing. Wydawnictwo Politechniki Łódzkiej, Łódź.

3. Jaska, E., Werenowska, A. (2018). Chatbots as a new communication tool for enterprise and clients. In: M. Podkowińska (ed.) Communication. Education. Culture. Pro Communio, Presov, p. 121.

4. K2Bots.AI (2019). Raport. Polskie Chatboty 2018 [Report. Polish Chatbots 2018]. Retrieved from: https://www.k2bots.ai/system/files/2019-01/RaportPolskie-chatboty-2018-K2.pdf [Access: 01.04.2019].

5. Lun, E. van (2018). An International Chatbots.org Survey: Consumers say No to Chatbot Silos. Chatbots.org news. Retrieved from: https://chatbots.org/conversational/agent/chatbots.org_report_consumers_chatbot_ usage_uk_us/ [Access 14.03.2019].

6. Nowy Marketing (2018). Encyklopedia marketing. Hasło: c-chat [Marketing encyclopedia. Word: c-chat]. Retrieved from: https://nowymarketing.pl/ a/19149,c-chatbot-encyklopedia-marketingu [Access 20.03.2019].

7. Pawlak, A., Wolski, M. (2007). The use of internet technologies of chatterbots in modern marketing activities. In: KIS 2007 - Konferencja Matematyki i Informatyki Stosowanej. Chełm 25-26.05.2007. Vol IV. Wydawnictwo Konferencyjne, Chełm. Retrieved from: http://www.kis.pwszchelm.pl/publikacje/IV/Pawlak. pdf [Access 20.03.2019].

8. Pyżalski, J. (2012). Agresja elektroniczna i cyberbullying jako nowe ryzykowe zachowanie młodzieży [Electronic aggression and cyberbullying as a new risky behaviour of young people]. Impuls, Kraków.

9. SALESmanago (n.d.). Automatic Sales Chat. Retrieved from: https://www.salesmanago.pl/marketing-automation/automatic_sales_chat.htm [Access 20.03.2019].

10. Taranko, T. (2015). Komunikacja marketingowa. Istota uwarunkowania, efekty [Marketing communication. The essence of conditioning, effects]. Oficyna Wolters Kluwer Business, Warszawa. 
Proceedings of the 2019 International Scientific Conference 'Economic Sciences for Agribusiness and Rural Economy' No 3, Warsaw, 5-7 June 2019, pp. 153-158

11. Wiktor, J.W. (2002). Modele komunikacji marketingowej [Marketing communication models]. Zeszyty Naukowe Akademii Ekonomicznej w Krakowie, 602, p. 122.

12. Wiktor, J.W. (2005). Promocja. System komunikacji przedsiębiorstwa z rynkiem [Promotion. Communica- tion system of a company with the market]. Wydawnictwo Naukowe PWN, Warszawa.

13. Wiktor, J. (2013). Komunikacja marketingowa [Marketing communication]. Wydawnictwo Naukowe PWN, Warszawa. 